\title{
Obituaries
}

Obituaries should be submitted by email to Jadene Doak at jadene.doak@springernature.com

All submitted obituaries should be 400 words maximum in length (apart from obituaries for past presidents of the BDA where the length should be 800 words).

Content of the obituary is down to the individual author, and the approval of the family should be given for the obituary prior to submission to the BDJ.

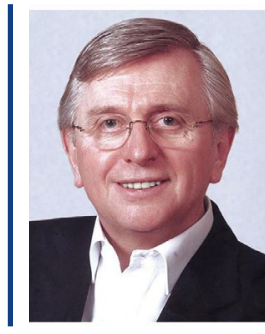

\section{David Phillips OBE}

$1943-2020$

David Phillips, who died in November 2020 after a short illness, was a man with vision, determination, and energy. Recognising early in his career that there was a need for a dentally orientated, occurrence-based indemnity society that was not financed by insurers, he convinced Medical Protection Society (MPS) that they needed Dental Protection - and DPL was born. David qualified from Bristol in 1963 and worked in general dental practice in Cardiff for 16 years before joining MPS in 1981, thence growing DPL with a fantastic team of likeminded and intelligent people that colleagues could rely on in times of need.

Many dentists benefitted from his wisdom and experience, and the dental profession is a safer and better place thanks to his foresight. Although DPL was his brainchild and first loyalty, he was also an active board member of Denplan during its developing years, becoming Chairman and ultimately Life President, going on to chair Oasis Dental as it was being established and lecturing internationally on healthcare risk management. When most dentists were thinking of retiring, David became Chairman of Two-Ten Health, a Dublin-based software company whose dental management software, Salud, is used in many dental schools and clinics worldwide.

His many appointments included; Specialist Adviser to the House of Commons Health Select Committee, in the wake of the 1992 fee cut (its report advocated prevention through continuing care, replacing the emphasis on dental treatment); lay member of the General Osteopathic Council, Treasurer and Chairman of its Disciplinary Committee; Elected Member of the GDC, chairing the Fitness to Practise Committee; medico-legal adviser to the WHO; Chairman of Barnet \& Edgware NHS Trust; Chairman of GetWellUK and of Dencare Ltd.; appointed OBE in 1994 for services to dentistry and in 1999, to the BDA's Roll of Distinction. Additionally, his charity work included being a trustee for Different Strokes and of Candoco, a charity that pairs amputee former professional dancers with able-bodied ballet partners in special choreographed performances. It is a truly inspiring and humbling charity to which he was devoted.

David leaves his much-loved family, Anne, also a dentist, and their daughter Rachel whom he adored. A great golfer, raconteur and lover of fine wines and dining, he was wonderful company to be with; generous, loyal, kind and supportive with huge energy. His wise counsel will be greatly missed by many but above all he will be missed by his family and many friends.

Meredyth Bell

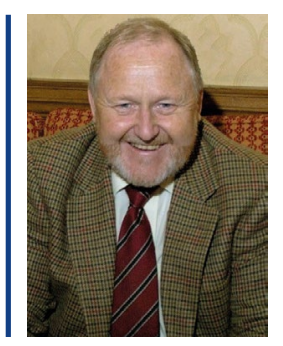

James S. Rennie

1949-2020

Dr Jim Rennie, who has died aged 71, transformed dental education in Scotland and made a significant contribution to addressing the crisis in NHS dental provision in the early part of the new century.

The abiding memory of Jim, for many, will be his wonderful sense of humour, the twinkle in his eye, and the accompanying raucous laughter; however, his sense of fun, never far from the surface, belied the seriousness with which he took the important things in life.

Jim was a proud Coatbridge man who never forgot his Lanarkshire heritage. His father, the local dentist, encouraged him into the profession, and he graduated from the University of Glasgow in 1972. Choosing to specialise in oral pathology, and having completed his $\mathrm{PhD}$, he became a respected academic working for over 20 years in one of the busiest head and neck pathology units in the UK.

Jim soon took the opportunity to combine his clinical work with his love of education, lecturing at Glasgow Dental School and inspiring several generations of students. He was renowned for memorising every student's name from their photograph prior to meeting them and, as any undergraduate knows, the prospect of being singled out by name in a lecture significantly concentrates the mind. This was one of the many indications of the efforts Jim made to get the best out of his students, and his interest in the effectiveness of education drove much of his career. Later he was to extend his influence, regionally at first, to the west of Scotland, culminating in his appointment as Postgraduate Dental Dean for Scotland in 1999. In addition to this post, in 2004 he was appointed Deputy Chief Executive for NHS Education Scotland. Jim also served on the General Dental Council contributing to review groups and standing committees.

In recognition of his outstanding contribution, Jim was appointed CBE in the 2011 Queen's Birthday Honours for services to dentistry and had two educational facilities in Glasgow and Inverness - named after him.

After retiring from the NHS, Jim concentrated his life in Elie with his dog Ebony, enjoying the company of his family and close friends. 